\title{
Synthesis and biologically important of 2-mercaptobenthiazole (MBT)- clubbed Chalcone derivatives
}

\author{
Falguni Bhabhor ${ }^{a}, K_{\text {.Satish }}{ }^{b}$, Hiren Variya ${ }^{c}$, Vikram Panchal ${ }^{\mathrm{c}}$, \\ aDepartment of chemistry, Navjivan science college, Dahod(Guj)india. \\ ${ }^{b}$ Department of Genetics \& Plant Breeding, C.P.College of Agriculture, S.K.Nagar(Guj)india. \\ 'Department of chemistry, ShethM.N.Patel Science College, Patan(Guj)india.
}

E-mail: falguni2510@gmail.com

Keywords: 2-Mercaptobenzthiazole, Chalcone, Anti-fungal, Anti-bacterial

\begin{abstract}
In this present work base catalyzed method used for formation of Chalcone of(E)-4(3-(4-hydroxyphenyl)acryloyl)-5-methyl-2(p-tolyl)-1H-pyrazol-3(2H)-one (II) reacted with derivatives of S-benzo[d]thiol-2yl-2-chloroethanethioate $\left(\mathbf{I}_{\mathbf{a}-\mathbf{f}}\right)$ resulted in formation of corresponding derivatives of (E)-S-benzo[d]thiazol-2-yl 2-(4-(3-(5-methyl-3oxo-2(p-tolyl)-2,3dihydro-1H-pyrazol-4-yl)-3-oxoprop-1-en-1-yl)phenoxy)etanethioate( III $\left._{\mathbf{a - f}}\right)$ was confirmed by spectral characterization such as IR, ${ }^{1} \mathrm{H}$ NMR, LC-MS and elemental analysis. The compounds were screened for their antimicrobial properties against a broad panel Gram-positive and Gramnegative bacteria as well as fungi.
\end{abstract}

\section{INTRODUCTION}

1,3-Diaryl-2-propen-1-ones, commonly known as chalcones are prominent secondary metabolites and precursors of flavonoids and is flavonoids in plants, these compounds are usually prepared by base or acid catalyzed aldol condensation between aromatic aldehydes and ketones under the homogeneous condition. . They serve as starting material for the synthesis of a variety of heterocyclic compounds that are of physiological significance. Because of their different functionalities, these compounds confer biological activities, such as synthons for the production of fiveandsix-member ring systems [1,2] for example Pyrazoles [3],Pyrazolines [4], isoxazolines [5], aurones [6], pyrimidine [7],falvanones [8] and di-aryl cyclohexenones [9]. The biological activities of chalcones are equally wide ranging. In fact, not many structural templates can claim association with such a diverse range of pharmacological activities, among which antimicrobial [10], antileishmanial [11], anti-malarial [12], antifungal [13], anti-viral [14], anti-inflammatory [15], cytotoxicity [16], anti-tumor [17], nematicidal [18] and anti-oxidant [19] are widely cited.

There are numerous biologically active bicyclic molecules containing two hetero atoms. 2Mercaptobenzothiazole (MBT) is an important scaffold known to be associated with several biological activities, and its derivatives are manufactured worldwide for a wide variety of applications S-acethydrazide hydrazine [20], S-acyl [21]. MBT and their derivatives have attracted much attention of chemists and pharmacologists because of their broad spectrum of biological activities and applications as antifungal and antibacterial activities [22], fungicide, insecticide, sensitizer, and anti-scorching agent [23].

In the present communication, we report here a series of hybrid heterocyclic scaffolds by clubbing chalcone with 2-Mercaptobenzothiazole (MBT)[24], in the present study. The structures of the various synthesized compounds were assigned on the basis of infrared (IR), proton nuclear magnetic resonance spectroscopy $\left({ }^{1} \mathrm{H}-\mathrm{NMR}\right)$ spectral data, and elemental analysis. 
Step-1 Synthesis of derivatives of S-benzo[d]thiol-2yl-2-chloroethanethioate $\left(\mathbf{I}_{\mathbf{a}-\mathbf{f}}\right)$

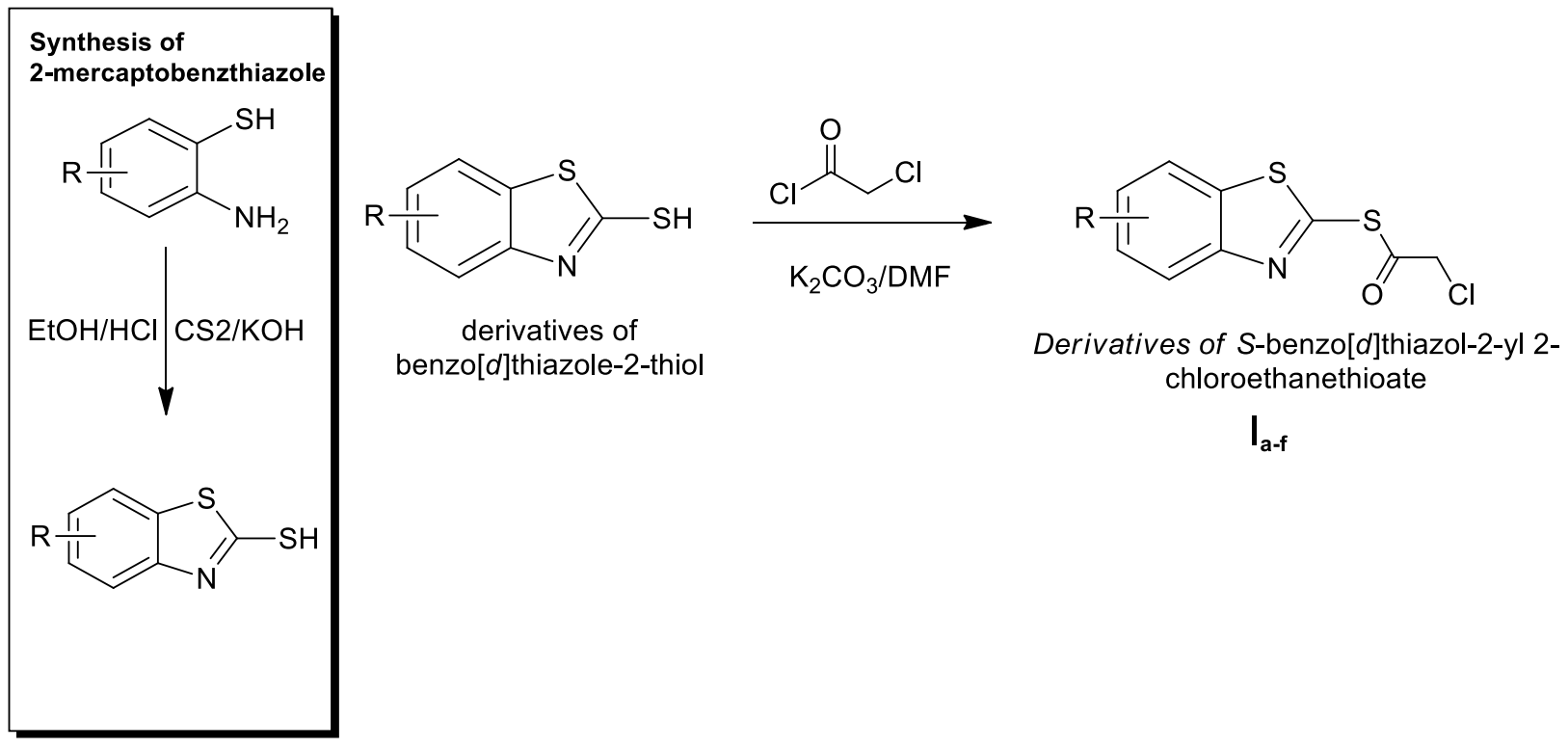
$\mathrm{R}=\mathrm{a}) \mathrm{H}$
d) $-\mathrm{NH}_{2}$
b) $-\mathrm{CH}_{3}$
e) $-\mathrm{NO}_{2}$
c) $-\mathrm{Cl}$
f) $\mathrm{F}$

Step-2 Synthesis of (E)-4-(3-(4-hydroxyphenyl)acryloyl)-5-methyl-2(p-tolyl)-1H-pyrazol-3(2H)one (II)

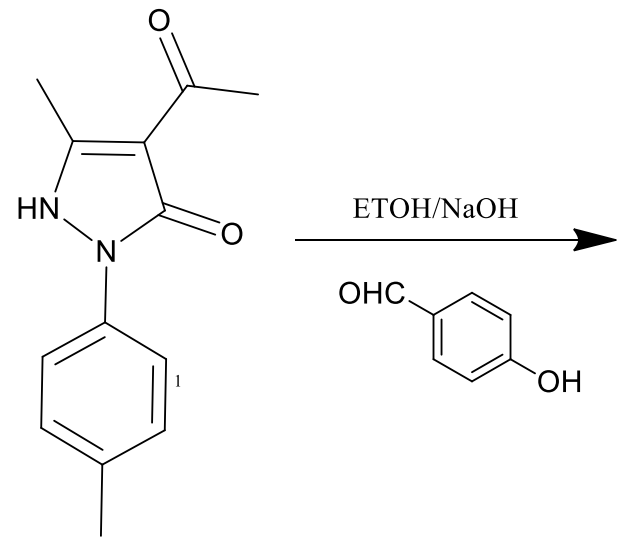

4-acetyl-5-methyl-2-(p-tolyl)-1H-pyrazol-3(2H)-one

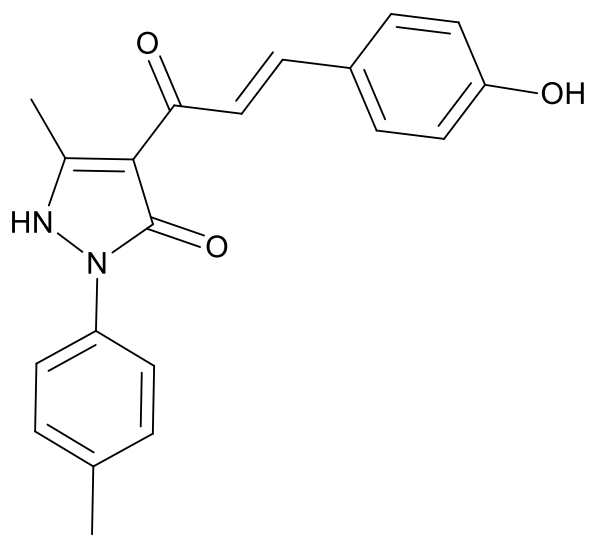

(E)-4-(3-(4-hydroxyphenyl)acryloyl)-5-methyl-2-(p-tolyl)-1Hpyrazol-3(2H)-one

II 
Step-3 Synthesis of titled compounds ( $\left.\mathbf{I I I}_{\mathbf{a}-\mathbf{f}}\right)$<smiles>O=C(CCl)Sc1nc2c(s1)C=C[R]C=C2</smiles><smiles>C=CC(=O)c1c(C)[nH]n(-c2ccc(C)cc2)c1=O</smiles>

II

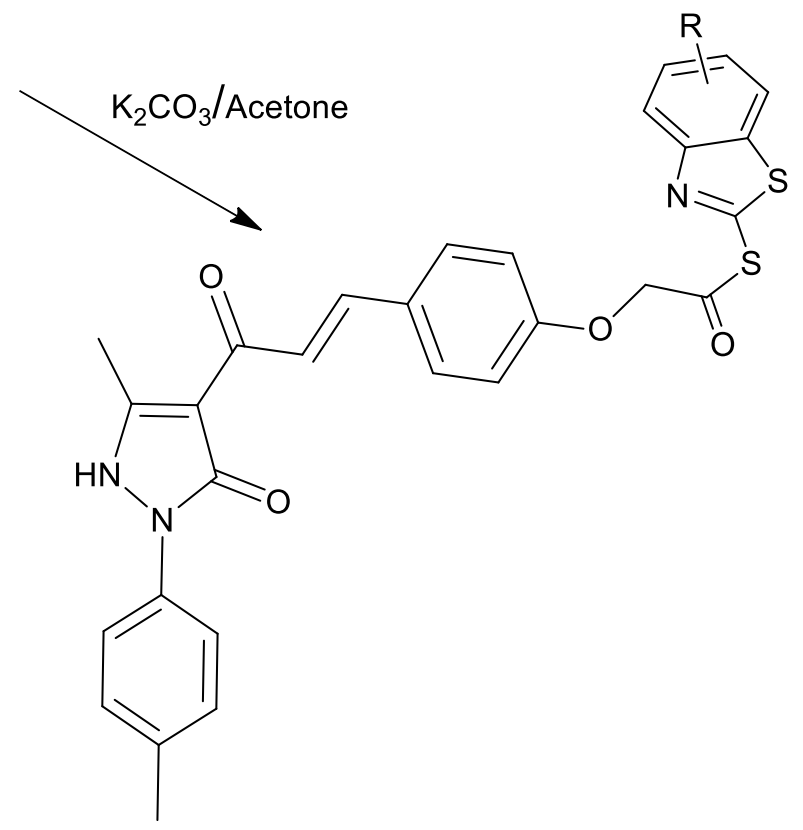

III

Scheme-1 Synthesis of compounds of ( III $\left._{\mathbf{a}-\mathrm{f}}\right)$

\section{RESULT AND DISCUSSION}

The synthetic route of the compounds is outlined in scheme-1. A series of titled compounds (III $\left.\mathbf{a}_{\mathbf{a}-\mathbf{f}}\right)$ were synthesized in three steps. Derivatives of S-benzo[d]thiol-2yl-2-chloroethanethioate $\left(\mathbf{I}_{\mathbf{a}-}\right.$ f) was prepared by reaction between different benzothiazole-2-thiol (where, initially prepare by different 2-amino benthiozole and carbon di-sulphide with $\mathrm{KOH}$ in EtOH) with chloro acetyl chloride and $\mathrm{K}_{2} \mathrm{CO}_{3}$ IN DMF. Synthesis of(E)-4-(3-(4-hydroxyphenyl) acryloyl)-5-methyl-2(ptolyl)-1H-pyrazol-3(2H)-one (II) were prepared by reacting $1 \mathrm{H}$ pyrazole containing acetaphenone with p-hydroxybenzaldehyde where $\mathrm{NaOH}$ was used as a base catalyst. This product (II) on reaction with the derivatives of $\left(\mathbf{I}_{\mathbf{a}-\mathbf{f}}\right)$ resulted in the formation of titled compounds $\left(\mathbf{I I I}_{\mathbf{a}-\mathbf{f}}\right)$ in good yield.

\section{CHARACTERIZATION}

\section{IR spectra}

The IR spectra of the titled compound ( III $_{\mathbf{a}-\mathrm{f}}$ ) (molecular formula $\mathrm{C}_{29} \mathrm{H}_{23} \mathrm{~N}_{3} \mathrm{O}_{5} \mathrm{~S}_{2}$ ) has given a weak absorption stretching vibration band observed at $2753 \mathrm{~cm}^{-1}$ confirmed the presence of methylene group in the final product. A sharp intensified band at $1647 \mathrm{~cm}^{-1}$ proves the presence of carbonyl group in the structure. The presence of $(-\mathrm{C}=\mathrm{C}-)$ in the aromatic ring was proved by absorbance at $1537 \mathrm{~cm}^{-1}$. The carbonyl functional group present in vicinity to the Chalcone $(-\mathrm{CH}=\mathrm{CH}-)$ has shown a sharp and intense absorption peak at $1669 \mathrm{~cm}^{-1}$. Another stretching vibration at $1591 \mathrm{~cm}^{-1}$ in the spectra of compounds ( III $\left._{\mathbf{a}-\mathbf{f}}\right)$.

\section{H $^{1}$ NMR}

$\mathrm{H}^{1}$ NMR spectra observed for the compound under investigation exhibited several absorption peaks corresponding to desired protons. A peak appearing particularly at $\delta=4.66$ confirmed the protons of methylene group in the final structure of aromatic rings.Also the appearing two broad peaks of two 
doublets at $\delta=7.15$ and $\delta=7.88$ confirmed the presence protons of two carbon atoms each of the chalcone group. The proton belonging to aromatic rings of the final molecule were found to correspond between the $\delta$ values 7.08-8.93.

\section{MATERIAL AND METHOD}

Melting points were determined in open capillary tubes and were uncorrected. The IR spectra were recorded by a perkin-Elmer 237 spectrophotometer and 1H NMR was recorded in DMSO with TMS as internal standard on Bruker. AM 400. Mass spectra were recorded on M S route JMS 600H. All the synthesized compounds were purified by recrystalization method. All the chemicals and solvents were A.R Grade and were used without further purification.

\section{GENERAL PROCEDURE}

Preparation of benzothiazole-2-thiol Substituted 2- amino thiophenol (0.01mol) was taken in R.B.F containing ethanol $(40 \mathrm{ml})$ and $\mathrm{KOH}(0.01 \mathrm{~mol}), \mathrm{CS}_{2}(0.02 \mathrm{~mol})$ was added to the well-stirred solution and reflux for $12-15 \mathrm{~h}$. The ethanol was then distilled off and cooled to room temp. The content was poured into ice coldwater and acidifies with dilute HCL till the precipitates were obtained. The separated solid was washed with cold water and dried to get desired product. The formation of titled intermediate was confirmed by the TLC.

Step-1 Preparation of derivatives of S-benzo[d]thiol-2yl-2-chloroethanethioate.

Take 2-marcapto benzthiazole $(0.01 \mathrm{~mol})$ in $10 \mathrm{ml}$ DMF. Dissolve it and then add 0.3 to $0.5 \mathrm{gm}$ $\mathrm{k}_{2} \mathrm{CO}_{3} \&$ stir it for $15 \mathrm{~min}$. Then add CAC $(0.01 \mathrm{~mol})$ drop wise at $0-5 \mathrm{c}$. \& stir the mix for $2 \mathrm{~h}$. After completion of reaction pour the mix. In cold water \& collect the product.

Step-2 Preparation of (E)-4-(3-(4-hydroxyphenyl) acryloyl)-5-methyl-2(p-tolyl)-1H-pyrazol3 (2H)one (II)

A mixture of aromatic aldehyde $(0.01 \mathrm{~mol})$ and 4-acetyl-3-methyl-1-(tolyl)-Pyrazole-5(4H)-one $(0.01 \mathrm{~mol})$ in $95 \%$ ethanol $(20 \mathrm{ml})$ were mixed in round bottom flask and $10 \mathrm{ml}$ of $60 \%$ of aq. Sodium hydroxide solution added drop wise. Resulting mix was stirred for at $5-10^{\circ} \mathrm{C}$, poured into crushed ice and acidified with dilute $\mathrm{HCl}$.The formation of titled intermediate was confirmed by observing the TLC using ethyl-acetate: hexane as a mobile phase.

Step-3 Preparation of titled compound.

Take 0.01 (mol.) (E)-4-(3-(4-hydroxyphenyl)acryloyl)-5-methyl-2(p-tolyl)-1H-pyrazole(2H)-one dissolve in acetone. To this solution different derivative were added $\& \mathrm{~K}_{2} \mathrm{CO}_{3}(0.02 \mathrm{~mol})$ was added to the above mix. Then it was allowed to stir for 4 hrat room temp. The completion of reaction was monitored using TLC plate using ethyl acetate: hexane as mobile phase.

3a. IR: $2890 \mathrm{~cm}^{-1}$ (C-H str. Of Ar.), $2753 \mathrm{~cm}^{-1}$ (methylene), 1663 \& 1593 (-CH=CH- of Chalcone), $1537 \mathrm{Cm}^{-1}\left(-\mathrm{C}=\mathrm{C}\right.$ - of Ar.), $1647 \mathrm{~cm}^{-1}$ (carbonyl group) Mass $(\mathrm{m} / \mathrm{z}): 541.1\left(\mathrm{M}^{+}\right) \mathrm{NMR}: 2.12 \& 2.20(\mathrm{~s}$, $3 \mathrm{H}), 4.66$ (s, 2H, methylene), $7.15 \& 7.88(\mathrm{~d}, 1 \mathrm{H}), 7.08-8.93(4 \mathrm{H}, \mathrm{d}, \mathrm{Ar}-\mathrm{H})$

3b. IR: $2893 \mathrm{~cm}^{-1}$ (C-H str. Of Ar.), $2755 \mathrm{~cm}^{-1}$ (methylene), $1663 \& 1593$ (-CH=CH- of Chalcone), $1539 \mathrm{Cm}^{-1} \quad\left(-\mathrm{C}=\mathrm{C}-\right.$ of Ar.),1645 $\mathrm{cm}^{-1}$ (carbonyl group) 2950-1370 (- CH3)Mass $(\mathrm{m} / \mathrm{z})$ : 555.07( $\left.\mathrm{M}^{+}\right) \mathrm{NMR}: 2.10 \& 2.24(\mathrm{~s}, 3 \mathrm{H}), 4.69(\mathrm{~s}, 2 \mathrm{H}$, methylene), $7.11 \& 7.91(\mathrm{~d}, 1 \mathrm{H}), 7.08-8.93(4 \mathrm{H}$, $\mathrm{d}, \mathrm{Ar}-\mathrm{H})$

3c. IR: $2891 \mathrm{~cm}^{-1}$ (C-H str. Of Ar.), $2753 \mathrm{~cm}^{-1}$ (methylene), 1661 \& 1590 (-CH=CH- of Chalcone), $1531 \mathrm{Cm}^{-1}$ (-C=C- of Ar.), $1647 \mathrm{~cm}^{-1}$ (carbonyl group) 1075 ( $\mathrm{Ar} \mathrm{C}-\mathrm{Cl}$ ) Mass $(m / z): 575.0\left(\mathrm{M}^{+}\right) \mathrm{NMR}$ : $2.09 \& 2.20(\mathrm{~s}, 3 \mathrm{H}), 4.64(\mathrm{~s}, 2 \mathrm{H}$, methylene), $7.18 \& 7.86(\mathrm{~d}, 1 \mathrm{H}), 7.08-8.93(4 \mathrm{H}, \mathrm{d}, \mathrm{Ar}-\mathrm{H})$

3d. IR: $2896 \mathrm{~cm}^{-1}$ (C-H str. Of Ar.), $2758 \mathrm{~cm}^{-1}$ (methylene), 1660 \& 1593 (-CH=CH- of Chalcone), $1541 \mathrm{Cm}^{-1}\left(-\mathrm{C}=\mathrm{C}-\right.$ of Ar.), $1645 \mathrm{~cm}^{-1}$ (carbonyl group) $3375(-\mathrm{NH} 2) \operatorname{Mass}(\mathrm{m} / \mathrm{z}): 556.12\left(\mathrm{M}^{+}\right) \mathrm{NMR}$ : $2.17 \& 2.26(\mathrm{~s}, 3 \mathrm{H}), 4.72(\mathrm{~s}, 2 \mathrm{H}$, methylene), $7.21 \& 7.88(\mathrm{~d}, 1 \mathrm{H}), 7.11-8.96(4 \mathrm{H}, \mathrm{d}, \mathrm{Ar}-\mathrm{H})$

3e. IR: $2886 \mathrm{~cm}^{-1}$ (C-H str. Of Ar.), $2749 \mathrm{~cm}^{-1}$ (methylene), $1667 \& 1590$ (-CH=CH- of Chalcone), $1540 \mathrm{Cm}^{-1}$ (-C=C- of Ar.), $1647 \mathrm{~cm}^{-1}$ (carbonyl group)1535 (-N02) $\operatorname{Mass}(\mathrm{m} / z): 586.1\left(^{+}\right) \mathrm{NMR}$ : $2.10 \& 2.28(\mathrm{~s}, 3 \mathrm{H}), 4.67(\mathrm{~s}, 2 \mathrm{H}$, methylene), $7.14 \& 7.90(\mathrm{~d}, 1 \mathrm{H}), 7.11-8.91(4 \mathrm{H}, \mathrm{d}, \mathrm{Ar}-\mathrm{H})$ 
3f. IR: $2895 \mathrm{~cm}^{-1}$ (C-H str. Of Ar.), $2750 \mathrm{~cm}^{-1}$ (methylene), $1660 \& 1591$ (-CH=CH- of Chalcone), $1535 \mathrm{Cm}^{-1}$ (-C=C- of Ar.), $1648 \mathrm{~cm}^{-1}$ (carbonyl group) 1067(Ar C-F)Mass $(m / z): 559.1\left(\mathrm{M}^{+}\right) \mathrm{NMR}$ : $2.13 \& 2.21(\mathrm{~s}, 3 \mathrm{H}), 4.68(\mathrm{~s}, 2 \mathrm{H}$, methylene), $7.19 \& 7.91(\mathrm{~d}, 1 \mathrm{H}), 7.12-8.90(4 \mathrm{H}, \mathrm{d}, \mathrm{Ar}-\mathrm{H})$

Table-1 Analytical data and Elemental analysis of compounds3 (a-e)

\begin{tabular}{|c|c|c|c|c|c|c|c|c|c|c|c|}
\hline \multirow{3}{*}{$\begin{array}{l}\text { Com- } \\
\text { pound }\end{array}$} & \multirow{3}{*}{ M.F } & \multirow{3}{*}{$\begin{array}{l}\text { Yield } \\
(\%)\end{array}$} & \multirow{3}{*}{$\begin{array}{l}\text { m.p } \\
\left({ }^{0} \mathrm{C}\right)\end{array}$} & \multicolumn{6}{|c|}{ Elemental analysis } & \multirow{2}{*}{\multicolumn{2}{|c|}{$\% \mathrm{~S}$}} \\
\hline & & & & \multicolumn{2}{|c|}{$\% \mathrm{C}$} & \multicolumn{2}{|c|}{$\% \mathrm{H}$} & \multicolumn{2}{|c|}{$\% \mathrm{~N}$} & & \\
\hline & & & & Found & Calc. & found & Calc. & Found & Calc. & found & Calc. \\
\hline $\mathrm{a}$ & $\begin{array}{l}\mathrm{C}_{29} \mathrm{H}_{23} \mathrm{~N}_{3} \mathrm{O}_{4} \mathrm{~S}_{2} \\
541.11\end{array}$ & 70 & 189 & 64.29 & 64.31 & 4.30 & 4.28 & 7.77 & 7.76 & 11.82 & 11.84 \\
\hline $\mathrm{b}$ & $\begin{array}{l}\mathrm{C}_{30} \mathrm{H}_{25} \mathrm{~N}_{3} \mathrm{O}_{4} \mathrm{~S}_{2} \\
555.13\end{array}$ & 76 & 192 & 64.85 & 64.84 & 4.51 & 4.53 & 7.54 & 7.56 & 11.55 & 11.54 \\
\hline c & $\begin{array}{l}\mathrm{C}_{29} \mathrm{H}_{22} \mathrm{~N}_{3} \mathrm{O}_{4} \mathrm{~S}_{2} \mathrm{Cl} \\
575.07\end{array}$ & 71 & 201 & 60.48 & 60.46 & 3.87 & 3.85 & 7.31 & 7.29 & 11.15 & 11.13 \\
\hline d & $\begin{array}{l}\mathrm{C}_{29} \mathrm{H}_{24} \mathrm{~N}_{4} \mathrm{O}_{4} \mathrm{~S}_{2} \\
556.12\end{array}$ & 68 & 187 & 62.55 & 62.57 & 4.36 & 4.35 & 10.04 & 10.06 & 11.50 & 11.52 \\
\hline $\mathrm{e}$ & $\begin{array}{l}\mathrm{C}_{29} \mathrm{H}_{22} \mathrm{~N}_{4} \mathrm{O}_{6} \mathrm{~S}_{2} \\
586.10\end{array}$ & 70 & 191 & 59.38 & 59.37 & 3.80 & 3.78 & 9.56 & 9.55 & 10.40 & 10.93 \\
\hline $\mathrm{f}$ & $\begin{array}{l}\mathrm{C}_{29} \mathrm{H}_{22} \mathrm{~N}_{3} \mathrm{O}_{4} \mathrm{~S}_{2} \mathrm{~F} \\
559.10\end{array}$ & 73 & 187 & 62.23 & 62.24 & 3.95 & 3.96 & 7.50 & 7.51 & 11.47 & 11.46 \\
\hline
\end{tabular}

\section{ANTIMICROBIAL ACTIVITY}

A broad panel of microbes was used for testing the antibacterial and antifungal properties of the molecules synthesized. The samples were tested by standard protocols like micro-dilution method. Concentration of the test compounds were keeps constant $(500 \mathrm{ppm})$ during all the experiments. The bacterial, fungal and yeast cultures were maintained on Nutrient-Agar, potato-dextrose-agar and YEDP culture -tubes respectively and were sub cultured every fortnight and stored at O-5 c temp. Anti-bacterial tests were carried against gram positive and gram negative bacteria. The anti-fungal tests were carried against two fungal strains Saccharomyces and A. Niger. Compound $3 \mathrm{c}$ and $3 \mathrm{e}$ showed good activity.

\begin{tabular}{|c|c|c|c|c|}
\hline Compounds & E-Coli & B-subtilis & Saccharomyces & A. Niger \\
\hline $3 \mathrm{a}$ & 62.5 & 125 & 125 & 250 \\
\hline $3 \mathrm{~b}$ & 125 & 31.5 & 125 & 125 \\
\hline $3 \mathrm{c}$ & 125 & 125 & 250 & 250 \\
\hline $3 \mathrm{~d}$ & 62.5 & 31.5 & 125 & 250 \\
\hline $3 \mathrm{e}$ & 125 & 62.5 & 250 & 125 \\
\hline $3 \mathrm{f}$ & 62.5 & 125 & 125 & \\
\hline
\end{tabular}




\section{CONCLUSION}

In the present work, all the titled compounds were synthesized by condensation of Chalcone with derivatives of 2-marcaptobenzthiazole. All the synthesized compounds were studied for antimicrobial activity. Compound $3 \mathrm{c}$ and $3 \mathrm{e}$ shows good activity. All the synthesized compounds were characterized by spectral data.

\section{Acknowledgment}

The authors with express their gratitude to DahodAnajMahajanSarvajanic Education Society for laboratory facilities. For analytical work Sophisticated Instrumentation Center for Applied Research and Testing, Vidhyanagar, India.

\section{References}

[1] A.A.H. Abdel-Rahman, A.E.S. Abdel-Megied, M.A.M. Hawata, E.R. Kasem, M.T. Shabaan, Monatsheftefu_rChemie 138 (2007) 889-897.

[2] M. Kidwai, P. Misra, Syn. Commun. 29 (1999) 3237-3250.

[3] S.K. Tambe, N.S. Dighe, S.R. Pattan, M.S. Kedar, D.S. Muamade, Pharmacologyonline 2 (2010) 15-19.

[4] R. Gupta, N. Gupta, A. Jain, Ind. J. Chem. 49B (2010) 351-355.

[5] T. Shah, V.J. Desai, Serb. Chem. Soc. 72 (2007) 443-449.

[6] A. Detsi, M. Majdalani, C.A. Kontogiorgis, L.D. Hadjipavlou, P. Kefalas, Bioorg. Med. Chem. 17 (2009) 8073-8085.

[7] A. Solankee, G. Patel, S. Solankee, Oriental J. Chem. 24 (2008) 1035-1038.

[8] A. Kumar, S. Sharma, V.D. Tripathi, S. Srivastava, Tetrahedron 66 (2010) 9445- 9449.

[9] J.S. Ghomia, M. Taheria, M.A. Ghasemzadeh, Org. Prep. Proc. Int. 42 (2010) 485-489.

[10] R.C. Kamboj, R. Arora, G. Sharma, D. Kumar, C. Sharma, R. Joshi, K.R. Aneja, Pharm. Chem. 2 (2010) 157-170.

[11] C. Reichwald, O. Shimony, S.N. Sacerdoti, C.L. Jaffe, C. Kunick, Bioorg. Med.Chem. Lett. 18 (2008) 1985-1989.

[12] 11. Liu, M., Wilairat, P., \& Go, L. M. Journal of Medicinal Chemistry, 44 (2001), 4443.

[13] I. Karaman, H. Gezegen, M.B. Guerdere, A. Dingil, M. Ceylan, Chem. Biodiver. 7 (2010) 400-408.

[14] T.T. Dao, P.H. Nguyen, H.S. Lee, E. Kim, J. Park, S.I. Lim, W.K. Oh, Bioorg. Med.Chem. Lett. 21 (2011) 294-298.

[15] Y. Prasad, A. RajendraRao, R. SrinivasaRambabu, Asian J. Chem. 21 (2009)907-914.

[16] J. Guzy, K.J. Vaskova, Z. Rozmer, K. Fodor, M. Marekova, M. Poskrobova,P. Perjesi, FEBS Lett. 584 (2010) 567-570.

[17] 15. Miranda, C. L., Aponso, G. L. M., Stevens, J. F., Deinzer, M. L., \& Buhler, D. R. Journal of Agricultural and Food Chemistry, 48 (2000), 3876

[18] A. Saeed, O.B. Zachary, A. Hasan, G.L. Melissa, C.U. Alejandro, Bioorg. Med.Chem. 19 (2011) 2055-2073.

[19] B.P. Bandgar, S.S. Gawande, R.G. Bodade, N.M. Gawande, C.N. Khobragade,Bioorg. Med. Chem. 17 (2009) 8168-8173. 
[20] Khim Farm Zh. 18 (1984) 946-948.

[21] Holbova E, Sidoova E, Zemanova M, DrobnicovaChem. papers 44 (1990) 363-368.

[22] Lee JH, Kim JD.Bull Korean ChemSoc.18 (1997) 442-443.

[23] Ramadas K, Janarthanan N. Synth Commun. 29 (1999) 1003-1007.

[24] Vijay Patil, Kalpna.Tilekar, SonaliMehendole-Munj, Rhea Mohan, C.S.RamaaEur. J. Med. Chem.45 (2010) 4539-4544. 